\title{
Challenges in Financing Small and Medium Enterprises in Palestine
}

\section{Bayyoud M*and Sayyad N}

Al-Quds University, Jerusalem, Palestine, Israel

\begin{abstract}
The purpose of the study attempts to analyze the obstacles and challenges that face small and medium enterprises in Palestine. This study seeks to look at the importance of small and medium enterprises, and to identify the most important constraints faced by small entrepreneurs in obtaining the required funding in Palestine, and what are the most important impediments toward financing of small projects.

The investigation helped in identifying the major challenges of financing small and medium business and what to do in order to overcome these obstacles. It was also found that small enterprises are one of the most important key elements in achieving economic development in all countries of the world where it accounts for the highest percentage among all kinds of economic projects of all sizes.

A qualitative closed-ended survey was carried out for collecting data from managers and owners of 35 businesses in Palestine. The responses of 28 statements were collected in five different categories. The findings showed that the Obstacles facing the growth of small enterprises in Palestine by respondents was "Weakness of representative organizations that defend the interests of small businesses, as well as Lack of legal frameworks and incentives for small businesses.
\end{abstract}

Keywords: Challenges; Financing; Small and medium enterprises; Palestine

\section{Introduction}

Small and medium businesses are a phenomenon that imposed itself on the agenda of the economists and the politicians in the Arab world generally and in Palestine particularly. Small and medium businesses gained an increasing attention worldwide following the role, these enterprises played in the reconstruction of the economies of countries defeated in World War. The Small and medium businesses are more than $98 \%$ of the private sector in Palestine. Given the size of the contribution of these companies in the domestic product, their prosperity and stability necessarily reflect positively or negatively on the local economy. Especially, since the statistics indicate that they employ more than $45 \%$ of the total workforce. This indicates the real threat to the national economy in the event of an interruption or decline in the performance of these small businesses. Despite the distinction of the small businesses and enterprises in Palestine, they face many challenges and a number of them disappeared due to their inability to compete with other products. Most of these small businesses also offer services, they are nonproductive, they do not have factories or important operating ports and they rely mainly on agencies, distribution or investment. The specialists criticize this type of small businesses because their policy of employment does not depend on the efficiency; there is no spirit of teamwork among the staff in addition to the problems resulting from the death of adults and non-entrustment of authority to succeeding generations.

Small Projects is one of the most important pillars upon which the recovery of the economy and steadfastness, and therefore the need for the Palestinian economy in the development of small enterprises through the provision of appropriate support and appropriate to continue significantly affect, here it is clear that the provision of appropriate funding for these projects is a priority for its continuation.

\section{Literature Review}

Small enterprises constitute the main nerve to the economy of any country, whether developed or developing countries which have a high ability to provide employment opportunities and as a means to stimulate self-employment as well as they need to be relatively low capital cost to start the activity, as well as these projects are characterized by their ability to employ semi-skilled and unskilled, as it gives an opportunity for job training to upgrade skills and abilities, as well as low risk in it, as well as contribute to these projects to improve productivity and generate increased income [1].

To begin with, there is no general consensus on one definition of what constitutes a small enterprise. For example, a small enterprise in America would be considered a large enterprise in a developing country. Even within the same country, the evaluation of an enterprise varies according to the situation the country's economy is experiencing .Thus a business considered large at one stage might be defined as a small enterprise at another stage of economic development. Facilitate the comparison between the sectors and countries [2].

Small enterprises also receive significant support as they are seen as providing more opportunities for poorer people. This is in part as there are too few larger firm jobs. Over the last decade in Sub-Saharan Africa, the employment share of household and micro-enterprises increased more than formal enterprises as the labor force increased more rapidly than the formal sector could create jobs [3]. Smaller firms also tend to have lower entry requirements in terms of skills, education and qualifications. Small enterprises are also important employers of marginalised groups who have difficulties finding employment in larger firms. As such, many smaller businesses are survival enterprises, operating out of necessity rather than with intent to grow, providing the majority of the poor an opportunity to earn an income in the absence

*Corresponding author: Mohammed Bayyoud, Al-Quds University, Jerusalem, Palestine, Israel, Tel: 00972022756200; E-mail: bayoud2@yahoo.com

Received February 22, 2016; Accepted June 25, 2016; Published June 30, 2016 Citation: Bayyoud M, Sayyad N (2016) Challenges in Financing Small and Medium Enterprises in Palestine. Bus Eco J 7: 222. doi:10.4172/2151-6219.1000222

Copyright: (c) 2016 Bayyoud M, et al. This is an open-access article distributed under the terms of the Creative Commons Attribution License, which permits unrestricted use, distribution, and reproduction in any medium, provided the original author and source are credited. 
of any real alternative (CAFOD, 2011). Liedholm and Mead suggest that development agencies with a focus on poverty reduction should focus on such survival enterprises. Altenburg and Eckhardt also suggest SMEs play an important role in providing products and services to the poor, although comparisons to larger enterprises are still missing.

Small enterprises report more business obstacles than larger enterprises- however a debate exists on what the key obstacles are, with significant implications on policy responses. Access to finance is often viewed as the most significant obstacle, coming out as the top constraint in World Bank Enterprise Surveys of over 45,000 enterprises in 196 countries (Figure 1) [4].

This is in part as banks see small enterprises as higher risk and more expensive to service in proportion to the loan amount. Women-owned businesses are particularly handicapped as they have fewer security assets and weaker property rights [5]. However others challenge this. For instance [6] found that increased access to finance helps larger firms more, potentially as it can also drive up other costs for micro and small enterprises and help the competition.

Small enterprises also face significant obstacles in other aspects of the business environment, such as taxes and regulation, inflation, corruption and street crime [7-10]. As shown in Figure 2, infrastructure

\begin{tabular}{|c|c|c|}
\cline { 2 - 3 } & $\begin{array}{c}\text { Small } \\
\text { enterprises }\end{array}$ & SMEs \\
\hline $\begin{array}{c}\text { Employment } \\
\text { across countries }\end{array}$ & $16 \%$ & $46 \%$ \\
\hline $\begin{array}{c}\text { Job creation } \\
\text { across countries }\end{array}$ & $45 \%$ & $75 \%$ \\
\hline $\begin{array}{c}\text { Employment in } \\
\text { low income } \\
\text { countries }\end{array}$ & $23 \%$ & $51 \%$ \\
\hline $\begin{array}{c}\text { Job creation in low } \\
\text { income countries }\end{array}$ & $58 \%$ & $89 \%$ \\
\hline
\end{tabular}

Figure 1: Empolyment and job creation by firm size.

\begin{tabular}{l|c|c|c}
\cline { 2 - 4 } & Small & Medium & Large \\
\hline Access to finance & 1 & 1 & 3 \\
\hline Electricity & 2 & 2 & 1 \\
\hline Informality & 3 & 3 & \\
\hline Tax rate & & & \\
\hline Skills & & & 2
\end{tabular}

Figure 2: Top three reported constraints by firm size (IFC, 2013). is also a significant problem, in particular access to electricity, both for smaller and larger enterprises. However others highlight the variety in how the business environment affects smaller enterprises. Liedholm and Mead, argue it is more important for existing businesses that are growing rather than for micro and small enterprises establishment, with many starting-up with little or no recognition. Aterido et al, indicate that a weak business environment can displace activity from larger firms towards micro-enterprises. On the one hand, certain skills and competencies may be relatively poorly developed among SMEs, where education levels may be lower. However it is larger firms that report being constrained by insufficient labor skills. This may follow from many smaller firms not aiming to grow but survive, and requiring less formal skills. The World Bank highlights the emerging literature showing the particular importance of management practice in explaining firm productivity, and large variation of management scores by micro and small enterprise owners in Sub-Saharan Africa.

\section{What is a small enterprise?}

Definitions of small enterprises vary widely. Most commonly they are defined by e number of employees. The World Bank Enterprise Survey (WBES) classifies enterprises with 5-19 employees as small and those with 20-99 as medium. The World Bank Group in-house definition considers enterprises with 10-49 employees as small, 0-10 as micro-enterprises and 50-299 as medium-sized. Small enterprises can also refer to wider categories, for instance, of SMEs, Micro and Small Sized Enterprises (MSEs) and Micro, Small and Medium Sized Enterprises (MSMEs). In a review of 132 economies, around a third defined MSMEs as having up to 250 employees [11].

However critics highlight that certain groups tend to be excluded from such classification systems and subsequent studies. WBES only interview formal businesses with five or more employees, and exclude micro and informal enterprises. Even more so, studies tend to focus on the non-agricultural private sector and exclude family farming or wage agriculture. Some also argue that firm size categories are arbitrary and note that enterprise characteristics are better described by classifications such as ownership, degree of formality/informality and technological sophistication [12]. With this in mind, this page does not follow one definition, but instead aims to highlight relevant research and opinions across definitions.

\section{Job relation and employment by small and medium enter- prises}

Small enterprises are often justified by their significant employment share. Reviewing WBES data from 104 countries [13], found that nearly a fifth of jobs are with small enterprises (5-19 employees), and nearly a half are with SMEs (5-99), with both shares rising in low income countries (Figure 1). However this actually downplays the contribution of small enterprises as informal and micro-enterprises are excluded. Using household surveys in 13 Sub-Saharan African countries [14], Fox and Sohnesen found that formal enterprises, small and large, account for just $9 \%$ of employment, informal household and micro enterprises $15 \%$, and that, with $70 \%$, most people were employed in family farming. The key justification, though, is more often that small enterprises are especially effective at creating new jobs Ayyagari et al, also found that in countries where jobs increased, small firms accounted for nearly a half of new jobs and SMEs accounted for three quarters of jobs- again both figures rising in low income countries (Figure 2); both large (and not even including informal and micro enterprise contributions) and significantly larger than employment shares. 
However critics have argued against this blanket view of small enterprises. Firstly, the study does not look at enterprise survival rates. Using panel data from Ethiopia, Page and Söderbom found that when the lower survival rates of small enterprises are taken into account, job growth for large and small enterprises is essentially the same. Second, there is a large variety amongst enterprises. In their seminal study, Liedholm and classify micro and small sized-enterprises (MSEs) into new-starts, non-growing enterprises, small growers and graduates. Non-growing enterprises, carrying out survival activities, are most common. However graduate enterprises, starting small but growing to $10+$ staff, account for only $1 \%$ of MSEs but a quarter of new jobs created by existing MSEs. They suggest that it is the growing enterprises, in particular the graduates, that growth focused development agencies should support.

\section{How productive are small and medium enterprises}

Small enterprises are having lower levels of productivity. For instance, Page and Söderbom found that firms with 30 employees have twice as much value-added per worker than firms with 5 employees (for firms with 100 employees, it is three times as much), largely linked to smaller enterprises lower levels of capital stock per worker. Small firms are also less likely to engage in innovative activities, such as adding new product lines and incorporating new technologies [15]. This being said, others highlight that some small enterprises are very productive and innovative. For instance, looking at Sri Lanka [16] found that over a quarter of micro-enterprises engage in innovation, particularly marketing and product innovation.

A debate also exists over the degree to which they contribute to national productivity and competitiveness. Competitive advantages, such as flexibility and closeness to customers, can allow them to innovate and complement large firms; higher turnover rates can also accelerate market development. Altenburg and Eckhardt argue this is less pronounced in developing than developed countries, though, as most small enterprises focus on a few activities characterized by low entry barriers and tend not to generate innovation, complement largescale production nor spur structural change.

However, a counter-view is that in the longer term, the competitiveness of the overall economy, as driven by larger enterprises, will have a significant impact on the poor, for instance through changing the tax revenues available for social services and indirect employment impacts. The Making Markets Work for the Poor (M4P) approach that donors such as DFID, Sida and SDC have been supporting over the past few years emphasizes that enterprises are part of wider market systems, and that large-scale poverty reduction requires these systems, rather than only individual enterprises, to work more effectively. Further, critics also highlight that job quality is often worse at small enterprises, with lower incomes and less job security due to the lower enterprise survival rates. Smaller firms also generally have worse working conditions [17]. Informal jobs, in particular, have less safe working conditions, and generally neither benefits nor dependable severance pay [18].

\section{The role of government in supporting entrepreneurship}

Small and Medium-sized Enterprises (SMEs) in market economies are the engine of economic development. Owing to their private ownership, entrepreneurial spirit, their flexibility and adaptability as well as their potential to react to challenges and changing environments, SMEs contribute to sustainable growth and employment generation in a significant manner [12].
SMEs have strategic importance for each national economy due a wide range of reasons. Logically, the government shows such an interest in supporting entrepreneurship and SMEs. There is no simpler way to create new job positions, increasing GDP and rising standard of population than supporting entrepreneurship and encouraging and supporting people who dare to start their own business. Every surviving and successful business means new jobs and growth of GDP [11].

Therefore, designing a comprehensive, coherent and consistent approach of Council of Ministers and entity governments to entrepreneurship and SMEs in the form of government support strategy to entrepreneurship and SMEs is an absolute priority. A comprehensive government approach to entrepreneurship and SMEs would provide for a full coordination of activities of numerous governmental institutions (chambers of commerce, employment bureaus, etc.) and NGOs dealing with entrepreneurship and SMEs. With no pretension of defining the role of government in supporting entrepreneurship and SMEs, we believe that apart from designing a comprehensive entrepreneurship and SMEs strategy, the development of national SME support institutions and networks is one of key condition for success. There are no doubts that governments should create different types of support institutions:

1. To provide information on regulations, standards, taxation, customs duties, marketing issues;

2. To advise on business planning, marketing and accountancy, quality control and assurance;

3. To create incubator units providing the space and infrastructure for business beginners and innovative companies, and helping them to solve technological problems, and to search for know-how and promote innovation; and

4. To help in looking for partners. In order to stimulate entrepreneurship and improve the business environment for small enterprises [11].

\section{Private sector support programme to support palestinian small and medium enterprises (SMES)}

The Italian Ministry of Foreign Affair on behalf of the Republic of Italy and the Palestinian Liberal Organization for the Benefit of the Palestinian National Authority represented by the Ministry of Finance (MoF) has signed an agreement on 22 July 2004 entitled "Private Sector Development Programme to Support Small and Medium Enterprises (SMEs) through the Palestinian Banking System" in the value of Euro 25 million soft loan. A Financial Agreement was signed on May 5, 2005 between the Palestinian Ministry of Finance and the Artigiancassa S.p.A., which is the financial institution in charge of administering, on behalf of the Ministry of Economics and Finance (MOEF) of the Republic of Italy, the Revolving Fund for Development Cooperation, and has been entrusted by the MOEF of the Republic of Italy with full power to administer the above mentioned Financial Agreement. Ministry of Finance signed Framework On-lending Agreement on June 32010 with four eligible Palestine Private Banks to operate this credit line in accordance to agreements with the Italian Government. The onlending agreements between Ministry of Finance and banks became effective on October 2010 after fulfilling all related administrative and legal matters, most importantly the endorsement decision of The Palestinian Council of Ministers.

The Italian Credit Line aims to providing soft loans for Palestinian small and medium enterprises to finance purchasing equipment and 
services of Italian origin to develop their current production Palestinian National Authority Ministry of Finance lines or to introduce new production lines within the sectors of industry and the food processing and agricultural industry, and related services to those sectors. The total aggregate price of the Supply Contracts, for which a Loan is requested, must be relevant to goods and services of Italian origin for a quota not lower than $70 \%$ (The remaining 30\% of the total aggregate price of the Supply Contracts can be related to the supply of goods and services (or construction work) of local origin (from Palestine or neighboring Countries). The quota of $30 \%$ that is not tied to supplies of Italian origin should be included in the contracts established with Italian Suppliers.

\section{Methodology}

After reviewing the general as well as specific literature about the obstacles and challenges for small and medium businesses in Palestine, a structured survey questionnaire was prepared and distributed to the managers and business owners and administrative level personnel in 35 businesses in Palestine. The research strategy was to personal visit to small and medium business owners in Ramallah city, Nablus city, and Hebron city. The findings gathered were purely qualitative in nature [15]. The response were gathered for 28 close-ended statements prepared around the key issues and the challenges for small and medium business strategies in Palestine in resolving all the issues. SPSS was used for reporting the responses. Survey strategy was found useful for the present investigation to collect large amount of data within the limited timeframe. The entire data collection procedure was based on 14 days procedure. Graphical representation of the findings was given for clarifying the results effectively Karyn L. Neuhauser.

\section{Survey analysis}

The results of survey are given below. Frequency responses for agreement and standard deviation in the responses were measured for each 28 statements.

Ownership of the businesses can be determined from Table 1 $55.0 \%$ of the samples are Individual; while, $30.0 \%$ are Family, $15.0 \%$ are Partnership (Table 1).

Table 2 confirms that $75.0 \%$ of the samples are yes, while, $25.0 \%$ are no, which shows that small businesses play distinguished role in the reconstructing the economies.
Table 3 suggest that $80.0 \%$ of the respondents answers yes, while, $20.0 \%$ answered no, which shows that small and medium businesses Contribute to employment and job creation, this also confirms form the literature review that small and medium business 10 create jobs not only in a developed countries but also in Europe and USA.

According to Table 4 shows that the Obstacles facing the growth of small enterprises in Palestine by respondents were "Weakness of representative organizations that defend the interests of small businessesece with mean score of (1.6). The second highest mean score was (1.8) for "Lack of legal frameworks and incentives for small businesses." The third highest mean score was (2.1) for, " Lack of political and economic stability and related ramifications on investment " and " keeping all marketing and exports channels in the hands of the Israelis ", and " Lack of marketing capacities and skills needed to enter markets."

Table 5 shows that the role of lending institutions to finance small projects by respondents was "Working on the granting of loans to increase the income of entrepreneurs ${ }^{\text {ecee }}$ with mean score of (1.4). The second highest mean score was (1.45) for "Trying, through lending in addressing the problem of poverty." The third highest mean score was (1.6) for, "Lending institutions are working on the advancement of society through loans provided by " determines that current risk assessment in Palestine; banks has improved in terms of assessment (100\%), reducing uncertainty (90\%) and periodic assessment (100\%) while foreign currency dependency and staff training is still demanding issues having negative consequences. Financial risk is not identified as key risk by $60 \%$ of respondents. The respondents were also asked what more challenges and obstacles faced by microfinance in Palestine is the paragraph which states "Difficult to pay the premiums due on the customer" averaging "2.7", while followed by a paragraph that states "Weak systems of control and follow-up by financial institutions ", averaging 12 arithmetic" 3.25 ", followed by a paragraph which states" Not provide the necessary guarantees for the loan "averaging" 3.4 ", while the lowest was in the paragraphs"

Weakness feasibility studies submitted by the customer ", where the arithmetic average of" 3.5 .

\begin{tabular}{|l|l|c|c|c|}
\hline & & Frequency & Percent & Valid Percent \\
\hline & Individual & 11 & 55.0 & 55.0 \\
\hline Valid & Family & 6 & 30.0 & 30.0 \\
\hline & & & & \\
\hline & Partnership & 3 & 15.0 & 15.0 \\
\hline & Total & 20 & 100.0 & 100 \\
\hline
\end{tabular}

Table 1: Ownership of the businesses.

\begin{tabular}{|l|c|c|c|c|}
\hline & Yes & 15 & 75.0 & 75.0 \\
\hline Valid & no & 5 & 25.0 & 25.0 \\
\hline & Total & 20 & 100.0 & 100.0 \\
\hline
\end{tabular}

Table 2: The importance of small projects in Palestine.

\begin{tabular}{|l|c|c|c|c|}
\hline & yes & 16 & 80.0 & 80.0 \\
\hline Valid & no & 4 & 20.0 & 20.0 \\
\hline & Total & 20 & 100.0 & 100.0 \\
\hline
\end{tabular}

Table 3: Frequency Percent Valid Percent Cumulative Percent. 
Citation: Bayyoud M, Sayyad N (2016) Challenges in Financing Small and Medium Enterprises in Palestine. Bus Eco J 7: 222. doi:10.4172/21516219.1000222

Page 5 of 5

Lack of political and economic stability and related ramifications on investment Keeping all marketing and exports channels in the hands of the Israelis. Weak infrastructure and the ramifications it leaves on cost increase Lack of legal frameworks and incentives for small businesses

Weakness of representative organizations that defend the interests of small businesses

Lack of management skills as the vast majority of small businesses Lack of marketing capacities and skills needed to enter markets Lack of information

Lack of capital and dependency on personal savings coupled with lack of cash flow management

\begin{tabular}{|c|c|c|c|c|}
\hline $\mathbf{N}$ & Minimum & Maximum & Mean & Std. Deviation \\
\hline 20 & 1 & 3 & 2.1000 & 0.55251 \\
\hline 20 & 1 & 4 & 2.1000 & 0.64072 \\
\hline 20 & 1 & 3 & 2.0500 & 0.82558 \\
\hline 20 & 1 & 3 & 1.8000 & 0.61559 \\
\hline 20 & 1 & 3 & 1.6000 & 0.59824 \\
\hline 20 & 1 & 4 & 2.3000 & 1.12858 \\
\hline 20 & 1 & 4 & 2.1000 & 0.96791 \\
\hline 20 & 1 & 4 & 2.1000 & 1.02084 \\
\hline
\end{tabular}

Table 4: Obstacles facing the growth of small enterprises in Palestine.

\begin{tabular}{|c|c|c|c|c|c|}
\hline & $\mathbf{N}$ & Minimum & Maximum & Mean & $\begin{array}{c}\text { Std. } \\
\text { Deviation }\end{array}$ \\
\hline Lending institutions to help in the creation of the Palestinian new projects & 20 & 1.00 & 4.00 & 1.7000 & .73270 \\
\hline Lending institutions are working on the advancement of society through loans provided by & 20 & 1.00 & 4.00 & 1.6500 & .74516 \\
\hline Endeavor to provide funding be adjusted in order to set up any project & 20 & 1.00 & 3.00 & 1.7000 & .80131 \\
\hline Seeking, through lending to increase employment & 20 & 1.00 & 3.00 & 1.9500 & .82558 \\
\hline Trying, through lending in addressing the problem of poverty & 20 & 1.00 & 3.00 & 1.4500 & .60481 \\
\hline Working on the granting of loans to increase the income of entrepreneurs & 20 & 1.00 & 3.00 & 1.4000 & .59824 \\
\hline
\end{tabular}

Table 5: The role of lending institutions to finance small projects.

\section{Conclusion}

The objective of this paper is to examine the obstacles facing the growth of small and medium enterprises in Palestine. The sample of 28 respondents was taking from the registered SMEs Palestine. The finding of this study shows that there are highly significant influence challenges and obstacles on SMEs performance in Palestine.

The survey showed Weakness of representative organizations that defend the interests of small businesses, legal frameworks and incentives for small businesses, Lack of political and economic stability and related ramifications on investment and keeping all marketing and exports channels in the hands of the Israelis and Lack of marketing capacities and skills needed to enter markets due to lack of

More challenges and obstacles faced by microfinance in Palestine which states "Difficult to pay the premiums due on the customer, "Weak systems of control and follow-up by financial institutions, guarantees for the loan and the Weakness of feasibility studies submitted by the customer.

\section{References}

1. Ademola IS, Michael AA (2012) Small Scale Businesses as a Remedy to Unemployment Problem in Nigeria. International Journal of Scientific \& Engineering Research 3: 71-76.

2. Bass, B.M (1985) Leadership and Performance beyond Expectations. New York Free Press.

3. Chittithaworn C, Islam MA, Keawchana T, Yusuf DHM (2011) Factors affecting business success of small \& medium enterprises (SMEs) in Thailand. Asian Social Science 7: 180

4. David FR (2003) Strategic management: concepts and cases. New Jersey: Pearson.

5. Finkelstein S, Harvey C, Lawton T (2008) Vision by design: a reflexive approach to entreprise regeneration. Journal of Business Strategy 29: 4-13.

6. Hair JF (2010) SEM: An introduction. Multivariate data analysis: A global perspective pp: 629-686.

7. Jasra JM, Khan MA, Hunjra Al, Rehman AU (2011) Determinants of business success of small and medium enterprises. International Journal of Business and Social Science 2 .
8. Kadiri IB (2012) Small and medium scale enterprises and employment generation in Nigeria: The role of finance. Kuwait Chapter of Arabian Journal of Business and Management Review 1: 79-93.

9. Kantabutra S, Avery GC (2010) The power of vision: statements that resonate Journal of Business Strategy 31: 37-45.

10. Kreiser PM, Marino LD, Kuratko DF, Weaver KM (2013) Disaggregating entrepreneurial orientation: the non-linear impact of innovativeness, proactiveness and risk-taking on SME performance. Small Business Economics 40: 273-291.

11. Kuratko DF, Hornsby JS, Goldsby MG (2007) the relationship of stakeholde salience, organizational posture, and entrepreneurial intensity to corporate entrepreneurship. Journal of Leadership \& Organizational Studies 13: 56-72.

12. Role of Small-businesses in the Palestinian Economy \& Impact of Recent Israeli Economic Sanctions and Measures, January 2001.

13. Samir Sous (2005) Small and medium- sized enterprises (SMEs) \& their role in economic development of Palestine, Ministry Of National Economy, Qalqilya District Office, Palestine-WB.

14. Small Enterprises center Demand and Needs of Micro and Small Enterprises for Business Development Services-BDS in Palestine and Impact of SEC Activities, Ramallah, Palestine, September, 2005.

15. A Synthesis of Lessons Learned: Microfinance, Evaluation office No. 3 December 1999

16. Ruit CVD (2002) Micro-finance, Donor Roles and Influence and the Pro-poor Agenda: The Cases of South Africa and Mozambique.

17. Tche J (2009) Role of microfinance saving in Cameroon: a neo-structuralist analysis. International Journal of Development Issues 8: 48-60.

18. Ahmed S (2009) Microfinance institutions in Bangladesh: achievements and challenges. 